\title{
New records of Argiope bruennichi (Scopoli, 1772) (Aranei: Araneidae) from Mordovia and adjacent regions of Russia
}

\section{О находках Argiope bruennichi (Scopoli, 1772) (Aranei: Araneidae) в Мордовии и сопредельных регионах России}

\author{
A.B. Ruchin, M.K. Ryzhov, O.N. Artaev, A.A. Khapugin \\ А.Б. Ручин, М.К. Рыжжов, О.Н. Артаев, А.А. Хапугин
}

The Smidovich Mordovian State Nature Reserve, Pushta, Temnikov District, Republic of Mordovia, 431230 Russia, e-mail: sasha_ruchin@rambler.ru

Мордовский государственный природный заповедник имени П.Г. Смидовича», пос. Пушта, Темниковский район, Республика Мордовия, 431230 Россия, e-mail: sasha_ruchin@rambler.ru

\author{
KEY WORDS: Argiope bruennichi, ecology, Mordovia. \\ КЛЮЧЕВЫЕ СЛОВА: Argiope bruennichi, экология, Мордовия.
}

ABSTRACT. New faunistic records, habitat preferences and abundance of Argiope bruennichi (Scopoli, 1772) in Mordovia and adjacent territories of Russia are provided.

РЕЗЮМЕ. Приведены сведения о фаунистических находках, предпочитаемых биотопах и численности Argiope bruennichi (Scopoli, 1772) в Мордовии и на сопредельных территориях России.

In recent years, apparently due to climate warming and aridization a number of invertebrates have extended their ranges. Many such invertebrates have been recorded in Mordovia and its neighbouring areas for the first time. For example, the sickle-bearing bushcricket, Phaneroptera falcata (Poda, 1761) [Saveliev, 1999; Ruchin et al., 2007], and the European mantis, Mantis religiosa (Linnaeus, 1758) [Bolshakov et al., 2010], have been spreading out northward, while the common cockchafer, Melolonta melolonta (Linnaeus, 1758), eastward [Bolshakov et al., 2013]. Yet, a number of steppe dwellers also increases; for example, Onconotus servillei Fischer von Waldheim, 1846, which has been simultaneously recorded by many entomologists in several forest-steppe regions of Russia [Mikhaylenko, 2008; Bakka, 2011; Ruchin, Mikhaylenko, 2013]. The wasp spider, Argiope bruennichi (Scopoli, 1772), as well as some of the aforementioned mentioned species, seems to have been expanding their ranges northward [Sacher, Bliss, 1990]. This spider species is known to be common in a number of European regions of Russia (see review Mikhailov et al., 2011; Borisova, 2012; Sozontov, 2012; Mikhailov, Borisova, 2013) and Belarus [Savarin, Ostrovsky, 2011].

The present papers provides new information on the findings of $A$. bruennichi in Mordovia and adjacent regions of Russia based on the material collected in 2006, 2008, 2009, 2011-2013. The date and locality, a total number of specimens and the collector's name for every finding are given (Fig. 1).

MATERIAL. Ryazan Region. Shilovsky Distr.: 1 - Avdotinka Vil., 17.VII.2006, 1 specimen (A. Ruchin); boundary between Sasovsky and Shatsky districts: 2 - between Novoe Berezovo and Rzhavets Vil., 10.VIII.2013, 5 specimens (A. Khapugin); $3-$ Rakovo Vil., 11.VIII.2013, 4 specimens (A. Khapugin); Tambov Region. Kotovsky Distr.: 4 - Kuzmino-Gat Vil., 3.VIII.2009, 1 specimen (O. Artaev). Nizhny Novgorod Region. Voznesensky Distr.: 5 -Marino Vil., 11.VIII.2009, 1 specimen (A. Ruchin). Republic of Mordovia. Zubovo-Polyansky Distr.: 6 - Yavas Vil., 5.VIII.2013, 1 specimen (A. Ruchin); 7 - Kiselevka Vil., 17.VII.2008, 1 specimen (A. Ruchin). Temnikov Distr.: 8 - Mordovia Natural Reserve, plot 422, 1.VIII.2011, 1 specimen (O. Artaev); Pushta Vil., 5.VIII.2012, 1 specimen (A. Ruchin); plot 448, 3.VIII.2013, 1 specimen (A. Ruchin); cordon Valzensky, 27.VII.2013, 1 specimen (A. Ruchin); cordon Drozhdenovsky, 18.VIII.2013, 2 specimen (A. Ruchin). Krasnoslobodsky Distr.: 9 Selishchi Vil., 11.VIII.2013, 8 specimens (A. Ruchin). Kovylkino Distr.: 10 - Alkino Vil., 4.VIII.2012, many specimens (M. Ryzhov). Staroshaygovsky Distr.: 11 - Lesnichestvo Vil., 7.VIII.2013, 2 specimens (A. Ruchin). Atyashevsky Distr.: 12 - Chebudasy Vil., 23.VIII.2012, 1 specimen (M. Ryzhov); 13 - Russkiye Dubrovki Vil., 2.VIII.2013, 2 specimens (M. Ryzhov). Chamzinsky Distr.: 14 - Chamzinka Vil., 21.VII.2013, 1 specimen (M. Ryzhov). Bolshebereznikovsky Distr.: 15 -Petrovka Vil., 10.IX.2011, 1 specimen (M. Ryzhov); 16 - Bolshiye Berezniki Vil., 18.VIII.2011, 1 specimen (M. Ryzhov); Ulyanovsk Region. Sura Distr.: 17 Baryshskaya Sloboda Vil., 8.VIII.2013, 1 specimen (O. Grishutkin).

All the aforementioned findings were made in JulySeptember. According to our observations, the typical habitats of $A$. bruennichi in Mordovia are mesophytic grasslands, wet clearings and the habitats near water sources (ponds, rivers, streams, lakes, springs). Spiders were observed on their webs situated in the grass near water. Additional findings were made in a holiday village, where spiders were observed mostly on flower beds. The species' abundance ranged from 1-2 individuals to more than 50 specimens per site.

Thus, A. bruennichi seems to be common in Mordovia, as well as in the adjacent regions of Russia. The number of records increased significantly after a hot 2010 summer, when many insect species began to spread 


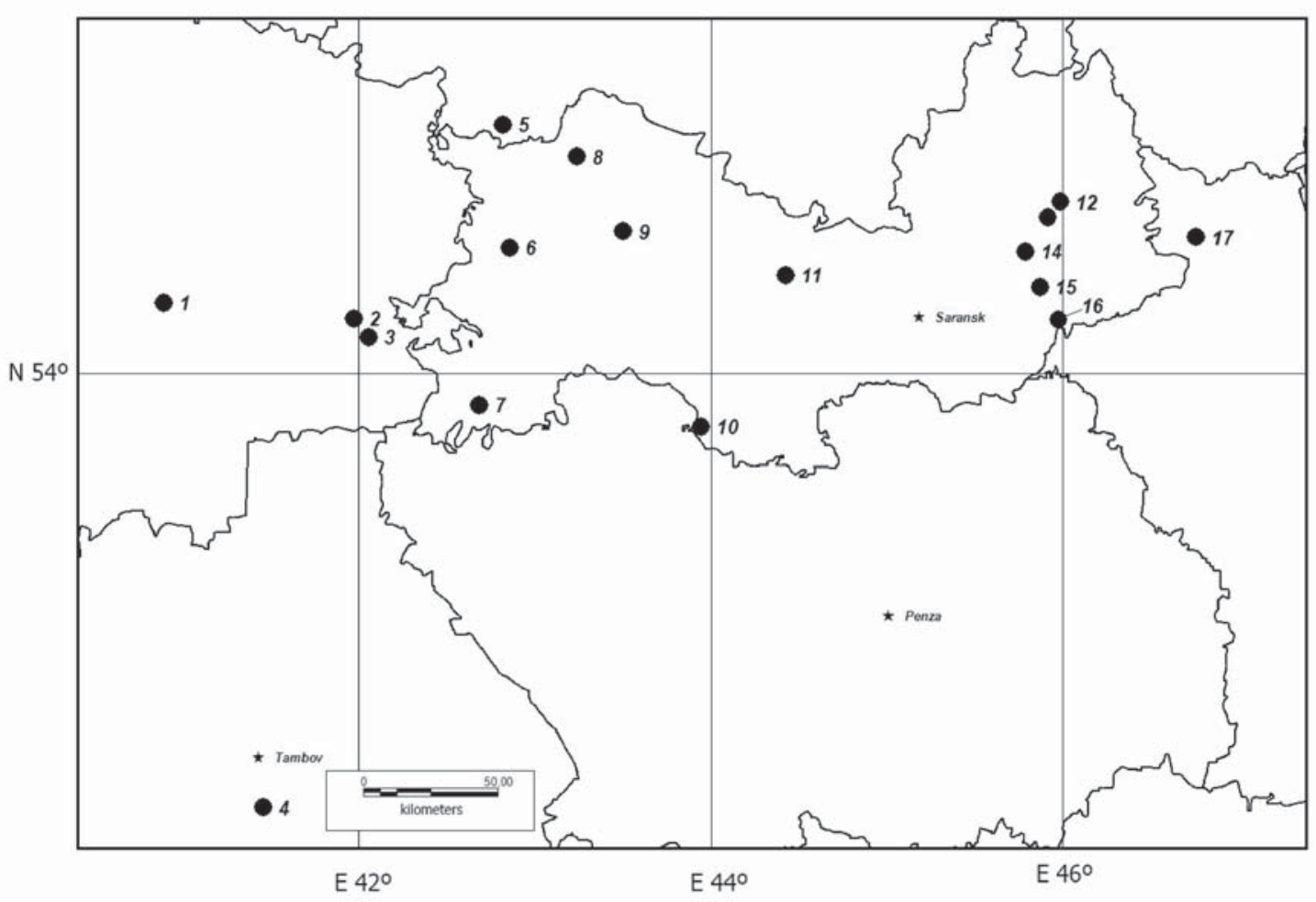

Fig. 1. Collecting localities of Argiope bruennichi (Scopoli, 1772) in Mordovia. See explanations in the text. Рис. 1. Места находок Argiope bruennichi (Scopoli, 1772) в Мордовии. Объяснения в тексте.

out northward. A. bruennichi can also be found in urban landscapes, apparently being accidentally introduced by man.

\section{References}

Bakka S.V. 2011. [A proposal to include Onconotus servillei to the Red Book of Nizhny Novgorod Region] // Redkie vidy zhivykh organizmov Nizhegorodskoi oblasti. Sbornik rabochikh materialov Komissii po Krasnoi knige Nizhegorodskoi oblasti. Nizhny Novgorod. Is.3. P.91-93 [in Russian].

Bolshakov L.V., Alekseev S.K., Mikhaylenko A.P., Mazur S.G. 2013. [Spreading out of the common cockchafer Melolonta melolonta (Linnaeus, 1758) (Coleoptera: Scarabaeidae) in the central part of European Russia] // Trudy Mordovskogo gosudarstvennogo prirodnogo zapovednika imeni P.G. Smidovicha. Saransk, Pushta. Is.11. P.89-97 [in Russian].

Bolshakov L.V., Shcherbakov E.O., Mazur S.G., Alekseev S.K., Ryabov S.A., Ruchin A.B. 2010. [The northernmost findings of European mantis Mantis religiosa (Linnaeus, 1758) (Mantodea: Mantidae) in the European part of Russia] // Eversmannia. Entomological research in Russia and adjacent regions. Is.23-24. P.22-25 [in Russian].

Borisova N.V. 2012. [Wasp spider (Argiope bruennichi) in Chuvash Republic] // Materialy II Mezhdunarodnoi nauchno-prakticheskoi konferentsii pamyati doktora biologicheskikh nauk, professora Kozlova. Cheboksary. P.28-30 [in Russian].

Mikhaylenko A.P. 2008. [On the fauna of nematoceran orthopterous species (Orthoptera: Tettigoniidae, Gryllidae) new to Moscow Region] // Eversmannia. Entomological research in Russia and adjacent regions. Is.15-16. P.72-82 [in Russian].
Mikhailov K.G., Bolshakov L.V., Lakomov A.F., Andreyev S.A. 2011. [Records of the spider Argiope bruennichi (Scopoli, 1772) (Aranei, Araneidae) in Tula Region] // Euroasian Entomol. J. Vol.10. No.3. P.390-392 [in Russian, with English summary].

Mikhailov K.G., Borisova N.V. [Wasp spider - Argiope bruennichi (Scopoli, 1772) (Aranei, Araneidae), in Moscow, Moscow Region and its spreading northward] // Byull. Moskovskogo obshchestva ispytatelei prirody. Otdel biol. Vol.118. No.4. P.71-74 [in Russian, with English summary].

Ruchin A.B., Loginova N.G., Kurmaeva D.K. 2007. [On the insect fauna of two forestries in the National Park "Smolny" (Republic of Mordovia)] // Fauna I ekologiya nasekomykh. Rostovon-Don: TsVVR Publ. Is.1. P.24-33 [in Russian].

Ruchin A.B., Mikhaylenko A.P. 2013. [Onconotus servillei - a new species of the Mordovian fauna] // Mordovskiy zapovednik. No.4. P.12-13 [in Russian].

Sacher P., Bliss P. 1990. Ausbreitung und Bestandssituation der Wespenspinne (Argiope bruennichi) in der DDR - ein Aufruf zur Mitarbeit // Entomol. Nachr. Berlin. Bd.34. S.101-107.

Savarin A.A., Ostrovsky A.M. 2011. [Distribution of the spiders Argiope bruennichi (Scopoli, 1772) and Dolomedes plantarius (Clerck, 1758) in the south-east of Belarus] // Vestnik Vitebskogo gosudarstvennogo universiteta. Vol.1. No.61. P.5558 [in Russian].

Savelyev P.V. 1999. [Entomofauna of national park "Sebezhsky": Orthopteran insects Orthoptera] // Priroda Pskovskogo kraya. Vol.6. P.19-21 [in Russian].

Sozontov A.N. 2012. [The first finding of Argiope bruennichi (Aranei, Araneidae) in the Udmurt Republic] // Vestnik Udmurtskofo universiteta. Biologiya. Nauki o zemle. Is.4. P.152153 [in Russian].

Responsible editors D.V. Logunov, K.G. Mikhailov 